\title{
Verklaringen voor intergenerationele criminaliteit: Statische versus dynamische theorieën
}

\author{
Marieke van de Rakt, Stijn Ruiter, Paul Nieuwbeerta \& \\ Nan Dirk de Graaf ${ }^{1}$
}

\section{Summary}

Static versus dynamic theories as explanations for intergenerational transmission of crime

Parental criminal behaviour exerts a substantial impact on offspring criminal behaviour. Unfortunately however, the explanation for the intergenerational transmission of crime remains unclear. To compare and contrast two possible explanations, we address the question of whether the timing of a father's criminal acts predicts the likelihood that his children commit crime. According to static theories, the total number of criminal acts rather than the exact timing influences the likelihood of offspring criminal behaviour. According to dynamic theories, timing is crucial and children are more likely to engage in criminal behaviour after fathers have committed criminal acts. Results show that the total number of delinquent acts is an important predictor, and also that the exact timing plays an important role. In the year the father has been convicted, the likelihood that the child commits crime increases substantially and decays in the following years at a slower rate the more crimes the father has committed. Our results show that the rigorous assumptions of static theories require nuancing.

\section{Inleiding en onderzoeksvraag}

Verschillende onderzoeken hebben al aangetoond dat de samenhang tussen het criminele gedrag van ouders en het criminele gedrag van hun kinderen substantieel is (Besjes \& Van Gaalen, 2008; Rowe \& Farrington, 1997; Van de Rakt, Nieuwbeerta \& De Graaf, 2008) ${ }^{2}$. Het bestaande onderzoek beperkt zich echter voornamelijk tot het beschrijven van samenhangen tussen de aantallen delicten van vaders en kinderen. Verklarin- 
gen voor de overdracht komen daarbij nauwelijks aan de orde. Doel van deze bijdrage is mogelijke verklaringen voor de overdracht van criminaliteit van vaders op hun kinderen te toetsen. Om deze verklaringen te toetsen stellen we ons de vraag in hoeverre deze intergenerationele overdracht afhangt van het tijdstip waarop een vader delicten pleegt. Hebben kinderen bijvoorbeeld een grotere kans op het plegen van een delict als hun vader hun criminele gedrag niet voor hun geboorte, maar juist in de adolescentieperiode tentoonspreidt?

Binnen de levensloop en ontwikkelingscriminologie is decennialang een debat gaande over de stabiliteit van criminele levenslopen (o.a. Vold, Bernard \& Snipes, 1998; Nagin \& Paternoster, 2000). Er zijn twee stromingen theorieën te onderscheiden van waaruit tegenstrijdige voorspellingen zijn af te leiden over de invloed die het tijdstip waarop vaders criminaliteit plegen heeft op het gedrag van hun kinderen. We komen dan tot (deels) tegengestelde voorspellingen.

Eén groep theorieën veronderstelt dat er verschillen zijn tussen personen in hun geneigdheid delicten te plegen. In de literatuur wordt deze benadering ook wel 'population heterogeneity' genoemd (Nagin \& Paternoster, 200o). Deze theorieën stellen dat iedere persoon een bepaalde kans heeft op het plegen van delicten. Deze kans komt tot stand door bijvoorbeeld biologische oorzaken of opvoeding en de omstandigheden in de vroege kindertijd. Gebeurtenissen die daarna plaatsvinden zouden geen invloed meer hebben op het criminele gedrag. Om deze reden worden de verklaringen die tot deze stroming behoren, ook wel de statische theorieën genoemd. De bekendste statische theorie is de zelfcontroletheorie van Gottfredson en Hirschi (1990). Biologische theorieën, die veronderstellen dat crimineel gedrag een genetische oorzaak kent, zijn ook op te vatten als statische theorieën. De overdracht van crimineel gedrag van ouders op hun kinderen vindt volgens deze theorieën al heel erg vroeg in het leven van de kinderen plaats en is daarna onveranderlijk. Het tijdstip van delicten van een vader is derhalve niet belangrijk.

Een andere groep theorieën veronderstelt dat de geneigdheid tot het plegen van delicten gedurende het leven van mensen kan veranderen. Deze positie wordt in de literatuur ook wel 'state dependance' genoemd (Nagin \& Paternoster, 200o). Dit principe houdt in dat allerlei levensomstandigheden de kans om een delict te plegen kunnen beïnvloeden. Conventioneel gedrag, zoals het halen van een diploma of het vinden van een baan, verkleint de kans van een individu om delicten te plegen, terwijl onder meer het onderhouden van banden met criminele vrienden de kans om een delict te plegen kan vergroten (Sampson \& Laub, 1990). Verklaringen uit deze stroming worden vaak aangeduid met dynamische theorieën. Dynamische theorieën veronderstellen dat de invloed van ouders op de criminele carrière van hun kinderen ook na de 
kindertijd kan plaatsvinden, bijvoorbeeld doordat kinderen het gedrag van hun ouders leren. Het meeste onderzoek richt zich met name op het criminele gedrag van vaders, aangezien vrouwen (en dus moeders) veel minder delicten plegen.

In deze bijdrage zullen we toetsen in hoeverre statische en/of dynamische theorieën een verklaring kunnen bieden voor de intergenerationele overdracht van criminaliteit. We maken gebruik van een unieke grootschalige dataset waarmee we de complete levenslopen van kinderen (van 12 jaar tot 40 jaar) en hun vaders (van 12 tot 55 jaar) analyseren en de precieze tijdstippen van veroordelingen expliciet onder de loep nemen. Dit design stelt ons in staat om verklaringen uit de twee groepen tegenstrijdige theorieën te toetsen. We stellen in deze bijdrage de volgende vraag:

In hoeverre kunnen statische en/of dynamische theorieën een verklaring bieden voor de intergenerationele overdracht van criminaliteit?

\section{Eerder onderzoek}

Eerdere studies naar de intergenerationele overdracht van criminaliteit gaan - zoals gezegd - voornamelijk in op correlaties tussen aantallen delicten van vaders en aantallen delicten van kinderen (met name zonen). Eén van de belangrijkste studies naar intergenerationele overdracht van crimineel gedrag is de Cambridge Study in Delinquent Development (CSDD). Deze studie, aanvankelijk uitgevoerd door West, tegenwoordig door Farrington, volgt een populatie van 411 Londense jongens en hun families van het 8 e tot het 40 jaar door interviews te houden en officiële gegevens te verzamelen. De meeste van deze 411 jongens hebben nu ook zelf kinderen (Smith \& Farrington, 2004: Farrington, Lambert \& West, 1998). In verschillende artikelen zijn de relaties tussen het criminele gedrag van ouders, kinderen, broers en zussen onderzocht. Uit de CSDD blijkt ondermeer dat de correlatie tussen het aantal veroordelingen van vaders en het aantal veroordelingen van zonen .43 bedraagt (Rowe \& Farrington, 1997). De onderzoeksresultaten van de CSDD laten verder zien dat het precieze tijdstip van de veroordelingen van de ouders niet of nauwelijks van belang is voor de mate van intergenerationele overdracht. Ouders die hun laatste delict begingen voor de geboorte van hun kinderen, hadden ongeveer evenveel invloed op de kans dat hun zoon delicten ging plegen als ouders die pas veroordeeld waren na de geboorte van het kind (West \& Farrington, 1977).

De Criminele Carrière en Levensloop Studie (CCLS) is het grootste Nederlandse onderzoek naar criminele levenslopen en intergenerationele overdracht. Resultaten van de CCLS laten soortgelijke, zij het minder 
sterke verbanden zien als resultaten van de CSDD. Zo laten Van de Rakt, Nieuwbeerta en Apel (2009) zien dat de correlatie tussen de aantallen veroordelingen van vaders en zonen ongeveer .25 bedraagt (en tussen vaders en dochters .20). Daarnaast blijkt uit gegevens van de CCLS dat er wel degelijk een effect uitgaat van het tijdstip waarop de vaders delicten pleegden. Kinderen wier vaders langer doorgaan met het plegen van delicten hebben een grotere kans om zelf ook ooit een veroordeling te krijgen (Van de Rakt, Nieuwbeerta \& de Graaf, 2006). Oorzaken voor de verschillen in de sterkte van de verbanden tussen het Nederlandse en het Britse onderzoek kunnen liggen in de verschillen tussen de onderzoeksdesigns of aan de verschillen tussen landen.

Eén studie (Van de Rakt, Nieuwbeerta \& De Graaf, 2008) analyseerde al eerder de criminele levenslopen van kinderen van vaders met uiteenlopende criminele geschiedenissen. De resultaten op basis van de CCLS wijzen uit dat de criminele levenslopen van kinderen van vaders met uiteenlopende criminele geschiedenissen van elkaar verschillen. Wat vorm betreft komen de levenslopen echter opvallend veel overeen met de typische leeftijd-criminaliteitscurve. Dat wil zeggen een curve met een relatief laag aantal delicten in de kindertijd, een snelle stijging tijdens de adolescentie en een piek in het midden van de 20 , waarna een gestage daling plaatsvindt. De verschillen betreffen echter voornamelijk verschillen in de hoogte van deze leeftijd-criminaliteitscurve. Deze eerdere studie vormt een mooie eerste beschrijving van de criminele levenslopen van kinderen wier ouders veroordelingen op hun naam hebben staan. In het onderhavige onderzoek zullen theoretische verklaringen aan de beschrijving worden toegevoegd.

De opzet van de CSDD en andere studies als de Pittsburgh Youth Study (o.a. Jaffee, Moffit, Caspi \& Taylor, 2003; Farrington et al., 2001) kennen echter verschillende andere beperkingen. Ten eerste gebruiken deze studies relatief kleine datasets, waardoor meer geavanceerde statistische toetsen niet kunnen worden toegepast. Ten tweede kennen de studies veelal een design waarin de respondenten geselecteerd worden op de afhankelijke variabele (crimineel gedrag van het kind) en de intergenerationele overdracht wordt overschat. Ten derde kennen de studies slechts een korte follow-upperiode en verzuimen zij in te gaan op de effecten van crimineel gedrag van de ouders tot in de volwassenheid van de kinderen. Ten slotte beperkt veel eerder onderzoek (ook eerder onderzoek met data van de CCLS) zich tot samenhangen in aantallen delicten tussen ouders en kinderen en verzuimt het in te gaan op de ontwikkeling van crimineel gedrag over de levensloop. Op alle vier genoemde punten boeken wij in deze bijdrage vooruitgang. 


\section{Van beschrijven naar verklaren: hypothesen op basis van ontwikkelingscriminologische theorieën}

In deze bijdrage zullen we verklaringen uit de twee stromingen binnen

de ontwikkelingscriminologie tegen elkaar gaan toetsen. Allereerst leiden we voorspellingen af over de invloed van het tijdstip van de gepleegde delicten van de vader uit de statische theorieën. Vervolgens leiden we voorspellingen af over de invloed van het tijdstip uit dynamische theorieën.

\section{I Statische theorieën}

Statische theorieën veronderstellen dat crimineel gedrag een onderdeel zou kunnen zijn van een groter geheel van onaangepast gedrag. Opvoeding in de vroege kindertijd zou deze vorm van overdracht bijvoorbeeld kunnen bewerkstelligen. Er zou ook een genetische verklaring aan het verband ten grondslag kunnen liggen. Biologische theorieën veronderstellen dat criminele vaders hun 'criminele' genen doorgeven aan hun kinderen die op hun beurt ook crimineel gedrag zullen vertonen. Van den Oord en Rowe (1997) vergelijken het criminele gedrag van 'volle' en 'half'- broers en -zussen, neefjes en nichtjes. Zij vinden beperkte aanwijzingen voor genetische overdracht. Onderzoek van Rodgers, Buster en Rowe (2001) laat wel bewijs zien voor een genetische oorzaak voor de overdracht in crimineel gedrag.

De zelfcontroletheorie van Gottfredson en Hirschi (1990) is misschien wel de bekendste statische theorie. Deze theorie gaat ervan uit dat crimineel gedrag geheel wordt veroorzaakt door een lage mate van zelfcontrole. Mensen met een lage mate van zelfcontrole vertonen risicovol gedrag, zijn kortzichtig en zijn uit op onmiddellijke behoeftebevrediging. Ze vertonen een breed spectrum van allerlei onaangepast gedrag. De belangrijkste veroorzaker van gebrekkige zelfcontrole zou liggen in het ineffectief opvoeden van de kinderen door de ouders. Wanneer ouders hun jonge kinderen niet goed in te gaten houden, corrigeren en bestraffen, zou de kans groter worden dat die kinderen een lage mate van zelfcontrole ontwikkelen. Gottfredson en Hirschi (1990) stellen dat zowel ouders met veroordelingen als ouders zonder veroordelingen hun kinderen niet zullen aanmoedigen om zelf delicten te plegen. Maar aangezien ouders met veroordelingen zelf weinig zelfcontrole zouden hebben en hun gedrag veelal gericht zou zijn op directe behoeftebevrediging, zijn zij veel minder goed in staat om kinderen op te voeden. Zij zullen normovertredingen minder vaak als zodanig herkennen en ook minder vaak corrigeren. Ouders met weinig zelfcontrole (en veel veroordelingen) verkrijgen via dit mechanisme dus ook kinderen met weinig zelfcontrole (en veel veroordelingen). Gottfredson en Hirschi veronderstellen dat de zelfcontrole 
na de kindertijd stabiel blijft. Mensen met weinig zelfcontrole hebben in alle omstandigheden gedurende hun gehele levensloop meer kans op het plegen van delicten.

De zelfcontroletheorie veronderstelt dat naarmate een vader vaker delicten pleegt, de kans groter wordt dat zijn kinderen ook meer delicten gaan plegen. Volgens de statische theorieën kunnen er dus wel verschillen zijn in de kansen op het plegen van delicten tússen mensen, maar er kunnen geen veranderingen optreden bínnen individuen. De typische leeftijd-criminaliteitscurve (waaruit blijkt dat de kansen op veroordelingen in bepaalde leeftijdsgroepen groter zijn) wordt door statische theorieën op de volgende manier verklaard: elk individu doorloopt de typische leeftijd-criminaliteitscurve. In bepaalde fases (zoals de adolescentie) wordt iedereen aan meer gelegenheid blootgesteld om delicten te plegen dan in andere fases. In die fases pleegt iedereen daarom meer delicten. De verschillen tussen mensen uiten zich dan ook alleen in de hoogte van de curves en niet in de vorm. De curves van kinderen van vaders met veel delicten zullen aldus in ieder jaar een hoger verloop kennen dan kinderen wier vaders nooit delicten pleegden. Aangezien de zelfcontrole van vaders bepaalt in welke mate hun kinderen over zelfcontrole beschikken en deze zelfcontrole in zijn geheel verantwoordelijk is voor het criminele gedrag van mensen, stelden wij een (niet-causale) hypothese op.

Vaders-delictenhypothese: Wanneer een vader meer delicten pleegt, dan heeft het kind in ieder jaar grotere kans om ook delicten te plegen.

Uit de statische theorieën is ook af te leiden dat het precieze moment waarop een vader delicten pleegt geen invloed heeft op de kans op het plegen van een delict door een kind. Het aantal delicten dat een vader pleegt wordt bepaald door zelfcontrole en deze zelfcontrole is verantwoordelijk voor het aantal delicten dat een kind zal plegen. Of een vader delicten pleegt wanneer het kind 15 jaar oud is, of wanneer hij de delicten pleegt voor de geboorte van het kind heeft daarmee dus geen effect op de criminele levensloop van het kind.

Statische hypothese: Het precieze tijdstip waarop de vader delicten pleegt, heeft geen invloed op het verloop van de criminele carrières van zijn kinderen.

\subsection{Dynamische (leer)theorieën}

We gebruiken in deze bijdrage inzichten uit twee dynamische theorieen; de differentiële-associatietheorie (Sutherland, Cressey \& Luckenbill, 
1992) en de leeftijdsgebonden informele sociale controletheorie (Sampson \& Laub, 1990). Het meest centraal in onze bijdrage staat de differentiële-associatietheorie. Deze theorie gaat ervan uit dat crimineel gedrag op dezelfde manier wordt geleerd als ander 'normaal geaccepteerd' gedrag. Het grootste gedeelte van het leren van crimineel gedrag vindt plaats in intieme persoonlijke groepen, zoals in het gezin. Niet alleen de technieken die een persoon moet beheersen om crimineel gedrag te vertonen moeten worden aangeleerd, ook de motieven, waarden en houdingen die benodigd zijn om criminaliteit te plegen worden aangeleerd. Sterkere omgang met delinquenten zorgt ervoor dat mensen een grotere kans hebben dit allemaal aan te leren en crimineel gedrag te ontwikkelen (zie o.a. de theorieën van Sutherland, et al., 1992; Bruinsma, 1985; Akers \& Jensen, 2003). Juist de omgang met een criminele ouder, die een rolmodel vormt voor een opgroeiend kind, zou het criminele gedrag kunnen bepalen.

De differentiële-associatietheorie veronderstelt dat crimineel gedrag op eenzelfde manier geleerd wordt als normaal geaccepteerd gedrag. In deze bijdrage toetsen wij of er een leereffect uitgaat van het plegen van delicten door de vader. We veronderstellen dat wanneer kinderen geconfronteerd worden met crimineel gedrag van een vader (bijvoorbeeld omdat zij er getuige van zijn of omdat vader erover tegen zijn kinderen vertelt), zij deze confrontatie opslaan in hun geheugen. De kinderen hebben door het plegen van criminaliteit door de vader wellicht de kans gekregen om technieken en kennis over het plegen van delicten te leren. Daarnaast zal het deviante gedrag vanaf dat moment wellicht als (meer) normaal of zelfs als wenselijk worden gezien. Kinderen hebben daarmee na het plegen van criminaliteit door een vader een grotere kans dat zij zelf ook crimineel gedrag vertonen. Dit noemen wij het leereffect.

Leerhypothese: Wanneer een vader een delict pleegt, heeft een kind daarna een grotere kans om ook een delict te plegen.

Wanneer een vader vervolgens een tweede keer het criminele pad opgaat, wordt een kind nog eens geconfronteerd met zijn deviante gedrag. Deze confrontatie kan weer direct zijn als het kind ter plaatse is bij het plegen van het delict, of indirect als een vader zijn kinderen bijvoorbeeld over zijn werkzaamheden vertelt. Door de tweede confrontatie wordt het kind weer eens herinnerd aan het eerste delict. De (impliciete) normen worden nog eens herhaald. De benodigde kennis of technieken die zijn weggezakt na het eerste delict, worden weer herhaald. Het deviante gedrag zal in de ogen van het kind weer een beetje meer normaal zijn geworden. We verwachten dat wanneer een vader een tweede of een derde delict pleegt, het leereffect groter zal zijn. Meer blootstelling aan 
deviant gedrag geeft het kind sterker het idee dat dit wenselijk gedrag is dan wanneer een kind er een enkele keer mee te maken krijgt. We noemen dit een aanvullend leereffect. Sampson en Laub (1990) spreken in deze context vaak over 'cumulatieve nadelen'. De stijging van de kans op een delict zal na een herhaling dus groter zijn, dan dat de stijging van de kans bij een eerste delict was.

Aanvullende leerhypothese: Met ieder delict dat een vader pleegt, gaat de kans voor een kind om een delict te plegen extra omhoog.

Wanneer het langer geleden is dat een vader crimineel actief was, zal de herinnering van kinderen aan het criminele gedrag van de vader langzaamaan minder levendig worden. De geleerde kennis over de benodigde technieken over het criminele gedrag zal steeds meer wegzakken. Daarbij worden de normen en waarden behorende bij een criminele levensstijl niet meer bekrachtigd. Geleidelijk aan zal daarmee ook de kans dat een kind een delict pleegt weer dalen. Inzichten uit de psychologie en de biologie leren ons dat ervaringen uit het verleden zonder nieuwe bekrachtiging steeds minder saillant worden en wegzakken in het geheugen (Wixted \& Ebbesen, 1991; Ebbinghaus, 1913). De herinnering van een kind aan het criminele gedrag van zijn vader dooft langzaam uit. Naarmate de confrontatie met het gedrag van een vader langer geleden is, dan zal de verhoogde kans op het plegen van delict langzaam aan steeds meer gaan dalen. We noemen dit het vervaleffect.

Vervalhypothese: Naarmate het langer geleden is dat een vader een delict pleegde, zal de verhoogde kans op het plegen van een delict (het leereffect) dalen.

We verwachten een sterkere toename in de kans op het plegen van een delict door een kind als een vader vaker delicten heeft gepleegd (zoals weergegeven in de Aanvullende leerhypothese). De normen en waarden zijn bij meer delicten al sterker bekrachtigd en het geheugen is vaker geprikkeld. Uit psychologische leertheorieën (o.a. Wixted \& Ebbesen, 1991) volgt ook dat de herinnering na een tweede of een derde confrontatie minder snel zal afnemen. Het vergeten van de confrontatie gaat steeds langzamer, de herinnering aan delicten van vaders blijven steeds langer levend. Criminologische theorieën noemen dit wel een reinforcementeffect (o.a. Akers \& Jensen, 2003). Naarmate een kind meer confrontaties met crimineel gedrag van zijn vader heeft gehad dan zal het vervaleffect steeds minder snel verlopen. We noemen dit het bestendigingseffect. 
Bestendigingshypothese: Naarmate een vader meer delicten heeft gepleegd, verloopt de daling van de kans op het plegen van een delict door een kind (het vervaleffect) steeds minder snel.

\subsection{Aanvullende voorspellingen}

Inzichten uit de leeftijdsgebonden informele sociale-controletheorie van Sampson en Laub (1990) kunnen ons helpen te voorspellen in welke perioden in het leven van een kind het criminele gedrag van een vader juist veel invloed zal hebben op het (criminele) gedrag van zijn kind(eren). Daarmee kunnen we aanvullende voorspellingen doen waarmee we de dynamische theorieën aan extra toetsingen zullen onderwerpen. De leeftijdsgebonden informele sociale-controletheorie (Sampson \& Laub, 1990) stelt dat bepaalde veranderingen in de levensloop de kans op het plegen van een delict kunnen veranderen. In verschillende perioden in het leven zijn verschillende banden en omstandigheden van belang. Tijdens de kindertijd en in de adolescentiefase zijn voornamelijk de banden met de ouders en het succes op school belangrijk. Daarna spelen bijvoorbeeld de banden met het eigen gezin (trouwen en kinderen krijgen) en het succes op de arbeidsmarkt een grote rol.

We veronderstellen op basis van de leeftijdsgebonden informele sociale-controletheorie dat het leren van crimineel gedrag van de vader door zijn kinderen vooral zal plaatsvinden in de periode waarin de banden met de ouders van belang zijn. We verwachten daarom dus voornamelijk een overdracht van criminele gedragingen en vaardigheden van vaders op hun kinderen in de adolescentie. We veronderstellen ook dat het leereffect in deze periode groter is dan in de periode na de adolescentie. Daarbij verwachten we dat kinderen in de adolescentie (waarin banden met ouders sterk zijn) de opgedane kennis en vaardigheden om delicten te plegen minder snel vergeten dan in de periode daarna.

Adolescentiehypothese: Het leereffect zal vooral sterk zijn gedurende de adolescentie van een kind, terwijl het vervaleffect dan juist kleiner zal zijn.

Een belangrijke voorwaarde voor het aanleren van crimineel gedrag van een vader, is dat de vader ook betrokken is in het leven van een kind. Veel kinderen maken gedurende hun leven een scheiding van hun ouders mee (o.a. Fischer, 2004). De meeste kinderen blijven daarna bij hun moeder wonen (Fischer, de Graaf \& Kalmijn, 2005). De vader blijft in de meeste gevallen wel een rol spelen, maar is niet meer dagelijks aanwezig. Kinderen van gescheiden ouders worden aldus veel minder met de criminele activiteiten van hun vader geconfronteerd, dan kinderen wier ouders nog bij elkaar zijn. We veronderstellen daarom dat het leereffect 
na het meemaken van een echtscheiding veel kleiner zal zijn. Immers, de delicten die een vader pleegt na de scheiding worden gepleegd terwijl de vader niet meer bij zijn kinderen woont. De confrontatie van de kinderen met het criminele gedrag van hun vader is daarmee veel minder geworden. Daarnaast verwachten wij dat de herinnering aan een gepleegd delict veel sneller zal vervagen, omdat kinderen hun vader niet meer dagelijks zien.

Echtscheidingshypothese: Het leereffect zal na het meemaken van een echtscheiding veel kleiner zijn, terwijl het vervaleffect dan juist groter zal zijn.

In tabel 1 zijn de hypothesen afgeleid uit enerzijds de statische theorieën en anderzijds de dynamische theorieën nog eens samengevat.

Tabel 1 Overzicht van alle hypothesen

Statische theorieën

Vaders-delicten-hypothese

Wanneer een vader meer delicten pleegt, dan heeft het kind in ieder jaar een grotere kans om ook delicten te plegen.

Het precieze tijdstip waarop een vader delicten

Statische hypothese pleegt, heeft geen invloed op het verloop van de criminele carrières van zijn kinderen.

Dynamische theorieën

Leerhypothese

Aanvullende leerhypothese

Vervalhypothese

Bestendigingshypothese

Adolescentiehypothese

Echtscheidingshypothese
Wanneer een vader een delict pleegt, heeft een kind daarna een grotere kans om ook een delict te plegen.

Met ieder delict dat een vader pleegt, gaat de kans voor een kind om een delict te plegen extra omhoog.

Naarmate het langer geleden is dat een vader een delict pleegde, zal de verhoogde kans op het plegen van een delict (het leereffect) dalen.

Naarmate een vader meer delicten heeft gepleegd, verloopt de daling van de kans op het plegen van een delict door een kind (het vervaleffect) steeds Het leereffect zal vooral sterk zijn gedurende de adolescentie van een kind, terwijl het vervaleffect dan juist kleiner zal zijn.

Het leereffect zal na het meemaken van een echtscheiding veel kleiner zijn, terwijl het vervaleffect dan juist groter zal zijn. 


\section{Data}

In deze bijdrage maken we gebruik van de gegevens van de Criminele Carrière en Levensloop Studie (CCLS). De justitiële en levensloopgegevens van 4271 willekeurig gekozen mannen die in 1977 zijn veroordeeld, zijn verzameld bij de dataverzameling van CCLS-veroordeelden (Nieuwbeerta \& Blokland, 2003). Deze onderzoekspersonen zijn geselecteerd door middel van een representatieve steekproef van $4 \%$ van alle misdrijfzaken die in 1977 onherroepelijk werden afgedaan. Van deze onderzoekspersonen zijn de justitiële gegevens in 2003 opgevraagd bij het algemeen documentatieregister van de Justitiële Documentatiedienst. Deze gegevens bevatten informatie over alle veroordelingen van mensen. Het aantal veroordelingen is jaarlijks gemeten, beginnend vanaf het 12e levensjaar (omdat de leeftijdsgrens om justitieel vervolgd te worden in Nederland 12 jaar is). De data omvatten dus alle informatie over alle veroordelingen na het $12 \mathrm{e}$ jaar tot het moment van dataverzameling in 2003. De data geven alleen informatie over die delicten waarvoor een individu ook veroordeeld is. We nemen enkel misdrijven en geen overtredingen mee (verkeersovertredingen bijvoorbeeld worden niet meegenomen). De delicten die geanalyseerd worden in deze bijdrage zijn dus allemaal misdrijven; het betreft zowel lichte vergrijpen (zoals winkeldiefstal) als zware misdrijven zoals verkrachting en moord. Naast de justitiële data zijn ook gegevens over geboorte, sterfte en trouwen opgevraagd bij de Gemeentelijke Basisadministratie (GBA) en het Centraal Bureau voor Genealogie (CBG).

De gegevens van het CCLS-veroordeelden zijn in 2005 uitgebreid met gegevens over de justitiële contacten van de kinderen (CCLS-kinderen; Van de Rakt \& Nieuwbeerta, 2005). Uit gegevens van de GBA en het CBG blijkt dat de 4271 mannen samen 6921 kinderen die in 2005 boven de 12 jaar waren hebben gekregen. Van deze 6921 kinderen zijn begin 2006 de justitiële gegevens met behulp van uittreksels uit het algemeen documentatieregister van de Justitiële Documentatiedienst (OBJD: Onderzoeks- en Beleidsdatabase van de Justitiële Documentatiedienst) verkregen. Voor een completere beschrijving van de data en de dataverzameling verwijzen we naar Van de Rakt, Nieuwbeerta en De Graaf (2008). In tabel 2 geven we de beschrijvende statistieken van de gebruikte variabelen weer.

Ongeveer de helft van de kinderen is een man. Het aantal delicten dat een vader gedurende het leven pleegt, loopt van 1 tot 186 met een gemiddelde van 10,24. Er bestaat dus flinke spreiding in het aantal gepleegde delicten tussen vaders. Gemiddeld bestaat een gezin uit 3,21 kinderen. De leeftijd van die kinderen is gemiddeld 29,9. Na het 12e levensjaar van het kind plegen de vaders gemiddeld nog 3,9 delicten. Het grootste deel van de delicten wordt dus gepleegd voordat de kinderen 12 zijn. Onge- 
Tabel 2 Beschrijvende statistieken

\begin{tabular}{|c|c|c|c|}
\hline Variabelen & Gemiddelde & Range & $\mathbf{N}$ \\
\hline \multicolumn{4}{|l|}{ Tijdsconstante variabelen } \\
\hline Geslacht & 0,49 & $0-1$ & 6921 \\
\hline Aantal delicten vader over het gehele leven & 10,24 & $\mathrm{I}-186$ & 6921 \\
\hline Aantal kinderen binnen een gezin & 3,21 & $|-| I$ & 6921 \\
\hline Leeftijd & 29,9 & $12-79$ & 6921 \\
\hline \multicolumn{4}{|l|}{ Tijdsvariërende variabelen } \\
\hline Aantal delicten vader na leeftijd kind $=12$ & 3,86 & $0-163$ & 123630 \\
\hline Echtscheiding & 0,47 & $0-1$ & 123630 \\
\hline Dood vader & 0,09 & $0-1$ & 123630 \\
\hline \multicolumn{4}{|l|}{ Afhankelijke variabele } \\
\hline Delict (door kind) in een bepaald jaar & 0,05 & $0-1$ & 123630 \\
\hline
\end{tabular}

Bron: CCLS, 2009

veer de helft van de kinderen in deze dataset maakt een scheiding mee en bijna 10\% wordt geconfronteerd met de dood van een vader. Scheidingen en sterfte van de vader komen in deze (criminele) groep veel vaker voor dan in groepen zonder criminele vader (Van de Rakt, Nieuwbeerta \& De Graaf, 2006). De kinderen plegen delicten in 5\% van alle jaren.

\section{Analyse strategie}

De houdbaarheid van de hypothesen hebben we getest we door middel van eventhistoryanalyse met repeated events. We analyseerden een bestand waarin per kind per jaar na het $12 \mathrm{e}$ levensjaar een record is aangemaakt. Wanneer een kind is gestorven dan zijn de jaren na het overlijden uit het bestand verwijderd. Het totale bestand bestaat uit 123.630 persoonjaren en 6921 individuen. In elk jaar is weergegeven of een individu in dat jaar wel of niet is veroordeeld voor een delict. Via de procedure nlmixed in SAS hebben we een logistisch model voor de kans op een of meer delicten (veroordelingen) in een bepaald jaar geschat ${ }^{3}$. De procedure nlmixed stelde ons in staat om het niet-lineaire vervaleffect te modelleren. Daarnaast konden we met deze procedure rekening houden met het feit dat we geen onafhankelijke waarnemingen hadden, omdat we meerdere jaren binnen een persoon bekeken. We hebben door middel van een multilevelanalyse rekening gehouden met de geneste structuur van de data (episoden zijn genest binnen personen). Aangezien ons geen software bekend is waarin we niet-lineaire effecten 
kunnen schatten, terwijl er rekening wordt gehouden met meer dan 2 niveaus, konden we in dit artikel niet corrigeren voor de clustering van kinderen binnen vaders. We verwachtten echter dat dit onze conclusies geenszins zou beïnvloeden ${ }^{4}$.

In deze bijdrage schatten we in totaal vier modellen (zie tabel 3). We beginnen met een model met de controlevariabelen en het statische effect van het aantal delicten van de vader. Daarna schatten we een model waarin we het aanvankelijke leereffect en het vervaleffect hebben opgenomen. Vervolgens schatten we een model waarin we ook het aanvullende leereffect en het bestendigingseffect schatten. Ten slotte schatten we een model met daarin ook de extra effecten van scheiden en adolescentie. We beschrijven achtereenvolgens de vier modellen en de parameters die binnen elk model geschat worden.

\section{Model I}

In model 1 beginnen we met een aantal controlevariabelen. We schatten allereerst het leeftijdseffect. Net als Blossfeld en Huinink (1991), modelleerden we dit leeftijdseffect met twee log-variabelen: De eerste geeft de daling na de piek aan, terwijl de tweede maat de aanvankelijke stijging weergeeft. We kozen voor deze modellering en niet voor een traditionele modellering met een kwadratische term van leeftijd, omdat de leeftijdcriminaliteitscurve geen volledig symmetrische parabool is. Veel eerder onderzoek (o.a. Blokland, Nagin \& Nieuwbeerta, 2005; Gottfredson \& Hirschi, 1990; Moffit, 1993) laat immers zien dat de kans op een delict snel stijgt tijdens de adolescentie, een piek kent wanneer mensen begin twintig zijn en vervolgens langzaamaan gaat dalen. Ook al zouden onze data dit verloop niet laten zien, dan nog is deze procedure te prefereren aangezien het (met hetzelfde aantal vrijheidsgraden) geen symmetrie veronderstelt. Ten tweede schatten we het effect van het doodgaan van een vader, waarbij een 0 aangeeft dat de vader leeft terwijl een 1 aangeeft dat de vader gestorven is. Uit de literatuur blijkt immers dat kinderen wier vaders doodgaan een grotere kans hebben op het plegen van delicten (o.a. Harper \& McLanahan, 2004). Daarbij is de invloed van een criminele vader na zijn dood ineens uitgesloten. Ook schatten we het effect van echtscheiding, waarbij een o aangeeft dat de ouders bij elkaar zijn en een 1 aangeeft dat de ouders gescheiden zijn (of nooit zijn getrouwd). We controleerden voor echtscheiding omdat de literatuur laat zien dat mannen die veel delicten plegen een grotere kans hebben om te scheiden (Van de Rakt et al., 2008) en dat kinderen van gescheiden ouders een grotere kans hebben om delicten te plegen (McLanahan \& Sandefur, 1994). Daarbij namen we het aantal kinderen binnen een gezin mee. Literatuur laat namelijk zien dat des te meer criminaliteit vaders plegen, 
des te vaker en des te meer kinderen zij krijgen (Van de Rakt et al., 2006). Theoretisch valt bovendien te verwachten dat er binnen die grote gezinnen minder controle op de kinderen is (Gottfredson \& Hirschi, 1990). Ten slotte namen we geslacht mee, waarbij een 1 aangeeft dat het individu een vrouw betreft. In de literatuur zijn grote verschillen tussen jongens en meisjes te zien in het plegen van delicten (Van de Rakt et al., 2008).

Daarbij schatten we in model 1 de parameter voor het effect van het totaal aantal delicten van de vader. Statische theorieën veronderstellen dat individuen onderling verschillen in hun criminele geneigdheid en dat deze verschillen mede veroorzaakt worden door de verschillen in criminele geneigdheid van de vaders. Om zoveel mogelijk rekening te houden met deze criminele geneigdheid en om de Vaders-delictenhypothese te toetsen, namen we het totale aantal delicten dat een vader in zijn leven pleegde mee. Dit is de beste (indirecte) meting van de zelfcontrole van de vader. We veronderstellen dat het verschil tussen twee of drie extra delicten van de vader groter en belangrijker is dan het verschil tussen bijvoorbeeld 20 en 21 extra delicten. We kozen daarom voor een logtransformatie van het aantal delicten van een vader.

\section{Model 2}

In model 2 zijn naast de parameters die we in model 1 reeds schatten, ook de parameters voor het aanvankelijke leereffect en het vervaleffect meegenomen. We veronderstellen dat het criminele leren van een kind begint wanneer een vader het eerste delict pleegt ${ }^{5}$. Daarvoor is er aldus geen invloed van leereffecten. De hypothese luidt dat de kans op het plegen van een delict door een kind toeneemt in het jaar dat een vader een delict pleegt. Dit noemen wij het leereffect $\left(\beta_{1}\right)$. Als de vader in de jaren erna niets crimineels meer doet, impliceert de vervalhypothese dat het effect van de eerste ervaring met vaders criminaliteit af gaat nemen. Ofwel, per jaar dat verstrijkt (T) neemt de invloed af. Na verloop van tijd zal de kans op een delict voor een kind het oude kansniveau benaderen. Inzichten uit de psychologie en de biologie laten zien dat het vergeten van informatie of vaardigheden via een exponentiële afname verloopt (Ebbinghaus, 1913). Om die reden modelleerden we de afname (het vervaleffect $\beta_{2}$ ) volgens een functie van exponentiële afname. Een exponentiële functie biedt ook het voordeel ten opzichte van een lineaire functie dat deze asymptotisch het uitgangsniveau benadert. Aanvullende analyses (niet gepresenteerd) lieten bovendien zien dat een model met exponentiële afname een betere fit heeft dan een model met een lineaire afname. We legden vooraf geen beperkingen op aan de snelheid van de afname, maar lieten deze door het model schatten. We stelden alleen dat de vorm van de afname dus via exponentieel verval verloopt. 
De functie met het leereffect en het vervaleffect ziet er op de volgende manier uit:

$$
\ln \frac{\text { pwel }}{\text { pniet }}=\left(\beta_{1}\right) \cdot\left(\exp \left(-\frac{(T+1)}{\beta_{2}}\right)\right)+B \cdot X
$$

Hierbij is $\beta_{1}$ het leereffect, $\beta_{2}$ het vervaleffect en $\mathrm{T}$ het aantal jaren sinds een vader een delict pleegde. We nemen $\mathrm{T}+\mathbf{1}$, omdat we verwachten dat de invloed van de vader meteen tot stand komt en niet een jaar nadat er een delict is gepleegd. B staat voor de parameter van de vector en $\mathrm{X}$ voor de matrix van de overige covariaten.

We verwachten dat $\beta_{1}$ (de leerparameter) een positief effect zal hebben. In dat geval is er een toename van de kans op het plegen van een delict. Wanneer het leereffect een grotere waarde heeft, dan neemt de kans voor een kind op het plegen van een delict toe. We verwachten ook dat $\beta_{2}$ (de vervalparameter) een positief effect zal hebben. In dat geval neemt de kans op het plegen van een delict met de jaren steeds verder af. Naarmate het vervaleffect een grotere waarde heeft, is het verval steeds minder groot en blijft de kans op het plegen van een delict dus steeds langer hoog.

\section{Model 3}

In model 3 is het aanvullende leereffect en het bestendigingseffect toegevoegd. Het aanvullende leereffect en het bestendigingseffect spelen pas een rol als een vader meerdere delicten pleegt. Wanneer een vader een tweede keer een delict pleegt, verwachten we dat er boven op het aanvankelijke leereffect $\left(\beta_{1}\right)$ nog een extra effect zal zijn $\left(\beta_{1}+\beta_{3}\right)$. De toename in de kans op een delict voor een kind is dus extra groot bij een tweede (of een volgende) delict. Bij ieder delict dat erna komt, verwachten we dat er naast $\beta_{1}$ nog een extra leereffect $\left(\beta_{3}\right)$ bovenop zal komen.

De snelheid van de afname zou volgens de theorie van Ebbinghaus (1913) na iedere keer dat een persoon opnieuw wordt blootgesteld aan de prikkel (in dit geval een delict door de vader) een beetje langzamer moeten verlopen. We verwachten aldus dat het langer duurt voordat de kans weer op het oude niveau terug zal zijn. We hebben de toename van de kans door leren en de vervlakking laten afhangen van de afname door bestendiging van het aantal delicten dat een vader heeft gepleegd. We kozen wederom voor een log-transformatie van het aantal delicten van een vader. Deze logaritmische functie bleek ook beter te passen dan de lineaire functie. De functie voor model 3, met de leereffecten en vervalen bestendigingseffect ziet er op de volgende manier uit: 


$$
\ln \frac{\text { pwel }}{\text { pniet }}=\left(\beta_{1}+\left(\beta_{3} \cdot \ln (A)\right)\right) \cdot\left(\exp \left(-\frac{(T+1)}{\beta_{2}+\left(\beta_{4} \cdot \ln (A)\right)}\right)\right)+B \cdot X
$$

Hierbij is $\beta_{1}$ het leereffect, $\beta_{2}$ het vervaleffect, $\beta_{3}$ het aanvullende leereffect en $\beta_{4}$ het bestendigingseffect. $T$ is het aantal jaren sinds vader het laatste delict pleegde en $\mathrm{A}$ is het aantal delicten dat een vader na de 12e verjaardag van het kind pleegde. B staat weer voor de parameter van de vector en $\mathrm{X}$ voor de matrix van de overige covariaten. Een positieve parameter voor het aanvullende leereffect $\left(\beta_{3}\right)$ betekent dat de toename in de kans op het plegen van een delict steeds groter wordt. We verwachten aldus dat $\beta_{3}$ een positieve waarde zal hebben. Als vaders meer op hun kerfstok hebben, verloopt het verval langzamer en is het bestendigingseffect $\left(\beta_{4}\right)$ groter. We verwachten daarom dat de $\beta_{4}$ een positieve waarde zal hebben.

\section{Model 4}

Tot slot formuleerden we nog een tweetal aanvullende voorspellingen. We veronderstellen dat het constante leereffect groter zal zijn en het vervaleffect kleiner zal zijn in de jaren waarin ouders bij elkaar zijn, aangezien vaders dan relatief vaak in de directe omgeving van hun kinderen zijn. We schatten daartoe een aanvullend leereffect in de jaren dat ouders bij elkaar zijn. Daarnaast schatten we of er sprake is van versneld verval in de jaren dat de ouders gescheiden zijn.

We veronderstellen ook dat het leereffect groter zal zijn wanneer het kind in de adolescentiefase zit (leeftijd 12 tot en met 19). We namen daartoe een tweede set aanvullende effecten op voor het leereffect en het vervaleffect. De vergelijking voor model 4 ziet er als volgt uit:

$$
\begin{aligned}
& \ln \frac{\text { pwel }}{\text { priet }}=\left(\beta_{1}+\left(\beta_{3} \cdot \ln (A)\right)+\left(\beta_{5} \cdot S\right)+\left(\beta_{6} \cdot A d\right) .\right. \\
& \left(\exp \left(-\frac{(T+1)}{\beta_{2}+\left(\beta_{4} \cdot \ln (A)\right)+\left(\beta_{7} \cdot S\right)+\left(\beta_{8} \cdot A d\right)}\right)\right)+B \cdot X
\end{aligned}
$$

Hierbij zijn $\beta_{5}$ en $\beta_{6}$ de aanvullende leereffecten van echtscheiding (S) en adolescentie (Ad) en $\beta_{7}$ en $\beta_{8}$ de aanvullende vervaleffecten van echtscheiding en adolescentie. We verwachten dat $\beta_{5}$ een negatieve waarde zal hebben: na een echtscheiding is het leereffect waarschijnlijk kleiner. Voor $\beta_{6}$ verwachten we juist een positieve waarde: in de adolescentie zullen delicten van de vader juist een groter leereffect hebben. Voor $\beta_{7}$ verwachten we een negatieve waarde, aangezien we verwachten dat het verval na een echtscheiding sneller verloopt, terwijl we voor $\beta_{8}$ een positieve waarde verwachten, omdat het verval in de adolescentie juist minder snel zou verlopen. 


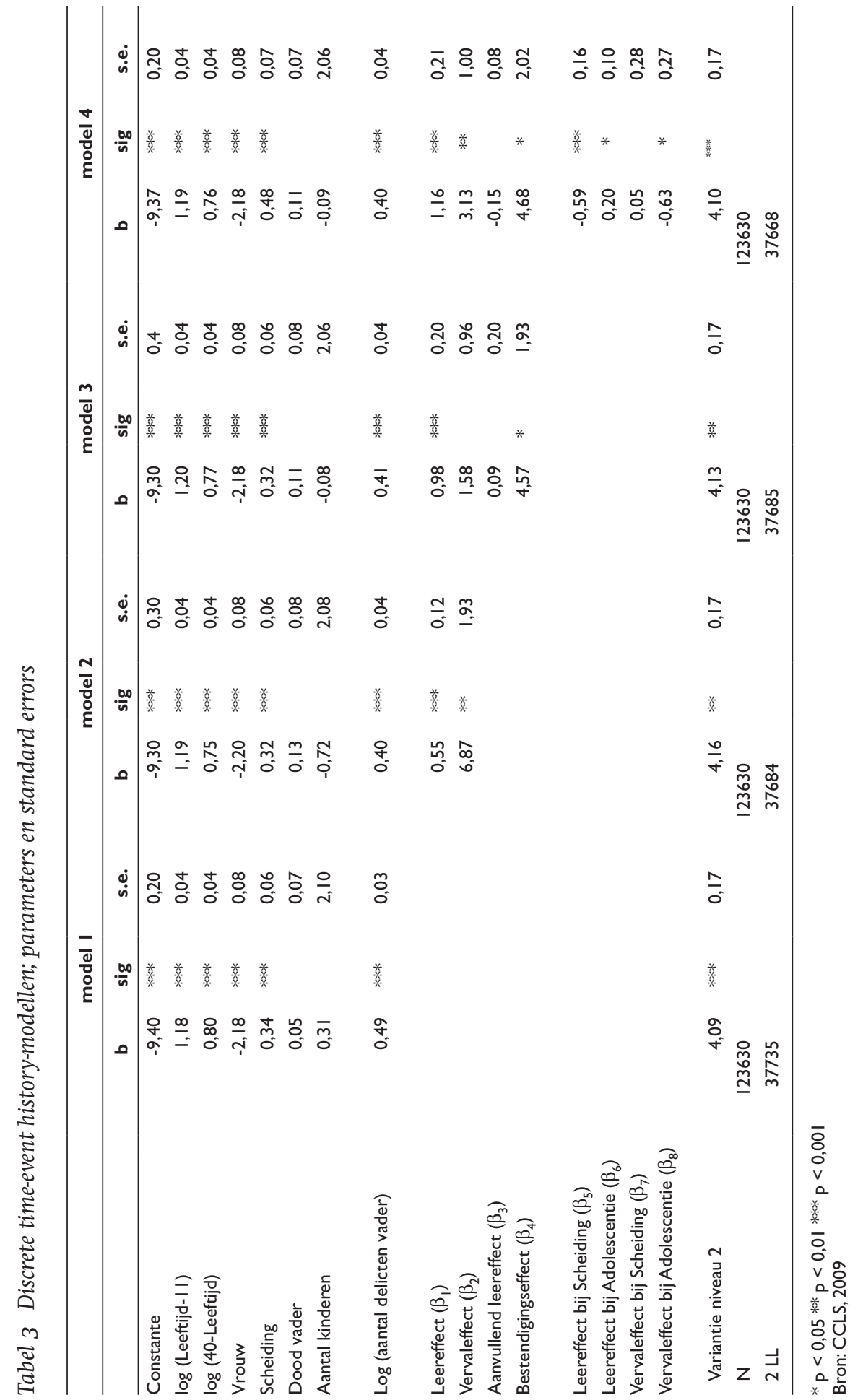




\section{Resultaten}

In model 1 van tabel 3 presenteren we effecten van leeftijd, geslacht, het scheiden van ouders, de dood van een vader en het aantal kinderen binnen een gezin. Daarbij toetsen we of het aantal delicten van een vader (over zijn gehele leven) een goede voorspeller van de kans op het criminele gedrag van een kind is. Uit model 1 blijkt dat de twee maten die gebruikt zijn om de leeftijdscurve te schatten, beide significant zijn. We zien dat de leeftijd-criminaliteitscurve asymmetrisch is. Wat opvalt, is dat de piek rechts van het midden ligt $((40+12) / 2=26)$. Dit is opmerkelijk, gezien de piek in eerder onderzoek meestal rond de vroege twintig wordt gevonden. Oorzaak voor deze bevinding kan zijn dat we hier werken met officiële veroordelingen, terwijl veel ander onderzoek zich baseert op zelfrapportages of politiestatistieken. Daarbij blijkt uit model 1 dat meisjes in ieder jaar een kleinere kans op een veroordeling hebben dan jongens. Vervolgens laat model 1 zien dat in de jaren dat ouders gescheiden zijn, kinderen een grotere kans hebben om delicten te plegen. In de jaren na de dood van een vader blijken kinderen echter geen verhoogde kans op het plegen van een delict te hebben. Ook het aantal broers en zussen van een individu blijkt geen invloed te hebben op de kans dat een kind een delict pleegt.

Belangrijkste bevinding uit model 1 is dat de delicten die een vader pleegt, een grote significante invloed hebben op de kans dat een kind een veroordeling krijgt. Deze bevinding ondersteunt de Vaders-delictenhypothese. De statische theorieën veronderstellen echter niet alleen de aanwezigheid van deze effecten, maar ook de áfwezigheid van allerlei leereffecten. In modellen 2, 3 en 4 bekijken we of dergelijke effecten inderdaad afwezig zijn.

In model 2 is het leer- en het vervaleffect toegevoegd. De geschatte parameter van het leereffect $\left(\beta_{1}\right)$ is significant positief. In het jaar dat een vader een delict pleegt, neemt de kans van een kind om een delict te plegen toe. De Leerhypothese wordt hiermee ondersteund. De geschatte parameter van het vervaleffect $\left(\beta_{2}\right)$ is ook significant positief. Naarmate het langer geleden is dat een vader een delict pleegde neemt de kans op het plegen van een delict door een kind (na de initiële stijging door het leereffect) weer af. De Vervalhypothese wordt dus ook bevestigd. De vervalparameter in model 2 is 6,87. Met de volgende vergelijking kunnen we de halveringstijd $(\mathrm{t} 1 / 2)$ berekenen:

$$
t \frac{1}{2}=\tau \ln 2
$$

De halveringstijd is het aantal jaren dat verstrijkt voordat de kans op het plegen van een delict door een kind weer gehalveerd is. Deze halveringstijd geeft ons meer inzicht in de snelheid van de vervalparame- 
ter. Op basis van de vervalparameter uit model 2 is de halveringstijd $6,87^{*} \ln (2)=4,76$.

In model 3 hebben we het aanvullende leereffect $\left(\beta_{3}\right)$ en het bestendigingseffect $\left(\beta_{4}\right)$ aan het model toegevoegd. Wie zien dat het aanvankelijke leereffect $\left(\beta_{1}\right)$ significant positief blijft, maar dat de parameter voor het aanvullende leereffect $\left(\beta_{3}\right)$ niet significant is. De kans op een veroordeling blijkt dus niet nog eens extra omhoog te gaan als een vader een volgend delict pleegt. De aanvullende leerhypothese moeten we aldus verwerpen. Het vervaleffect $\left(\beta_{2}\right)$ blijkt in model 3 niet meer significant te zijn, maar het bestendigingseffect $\left(\beta_{4}\right)$ heeft wel een positief significante parameter. De afname van het vervaleffect tussen de modellen 2 en 3 kan op de volgende manier worden geïnterpreteerd: in model 2 werd nog een redelijk grote algemene vervalparameter $\left(\beta_{2}\right)$ geschat. De bijhorende halveringstijd $(4,76)$ geeft aan dat het bijna vijf jaar duurt voordat de initiële stijging van de kans op een delict voor de helft is afgenomen. Kinderen wier vaders een delict plegen, behouden daarna aldus lange tijd een grote kans om ook een delict te plegen. In model 3 is het leerproces (en dus de vervalparameter) nader gespecificeerd. De vervalparameter $\left(\beta_{2}\right)$ geeft in dit geval het verval in de kans op een delict na het eerste delict van de vader weer. Het verval na dit eerste delict verloopt erg snel, gezien de kleine (niet significante) vervalparameter. De bijhorende halveringstijd is in dit geval $1,58^{*} \ln (2)=1,09$. Na iets meer dan een jaar is de kans alweer halverwege het oude niveau. Het bestendigingseffect in model 3 geeft aan wat er met het verval gebeurt nadat het eerste delict is gepleegd. Het bestendigingseffect $\left(\beta_{4}\right)$ is in model 3 echter wel significant positief. Naarmate een vader meer delicten pleegt, zal er meer bestendiging en minder verval optreden (getuige de significant positieve bestendigingparameter). Wanneer een vader bijvoorbeeld vijf delicten pleegt dan is de totale vervalparameter $1,58+\left(\ln (5){ }^{*} 4,57\right)=8,93$. De bijhorende halveringstijd is dan $8,93{ }^{*} \ln (2)=6,2$. Wanneer een vader dus vijf delicten pleegt, dan duurt het na het vijfde delict meer dan zes jaar voordat de kans op het plegen van een delict door een kind halverwege het oorspronkelijke kansniveau is. Het vervaleffect blijkt dus wel degelijk te bestaan, maar bij slechts één delict is het verval zo klein dat de bijhorende parameter niet significant is. De verhoogde kans op een delict door het leereffect is in het daarop volgende jaar alweer op het oude niveau. Bij meer dan één delict is er echter wel degelijk sprake van significant vervaleffect.

$\mathrm{Al}$ met al spreken deze resultaten de statische theorie tegen en bieden ondersteuning voor de dynamische leertheorie. Er blijken wel degelijk effecten te zijn van het precieze tijdstip van de delicten van de vader. Juist in de jaren nadat een vader een delict heeft gepleegd, is de kans voor kinderen om ook een delict te plegen verhoogd, hoewel dit met 
Figuur 1a Leereffecten over de levensloop

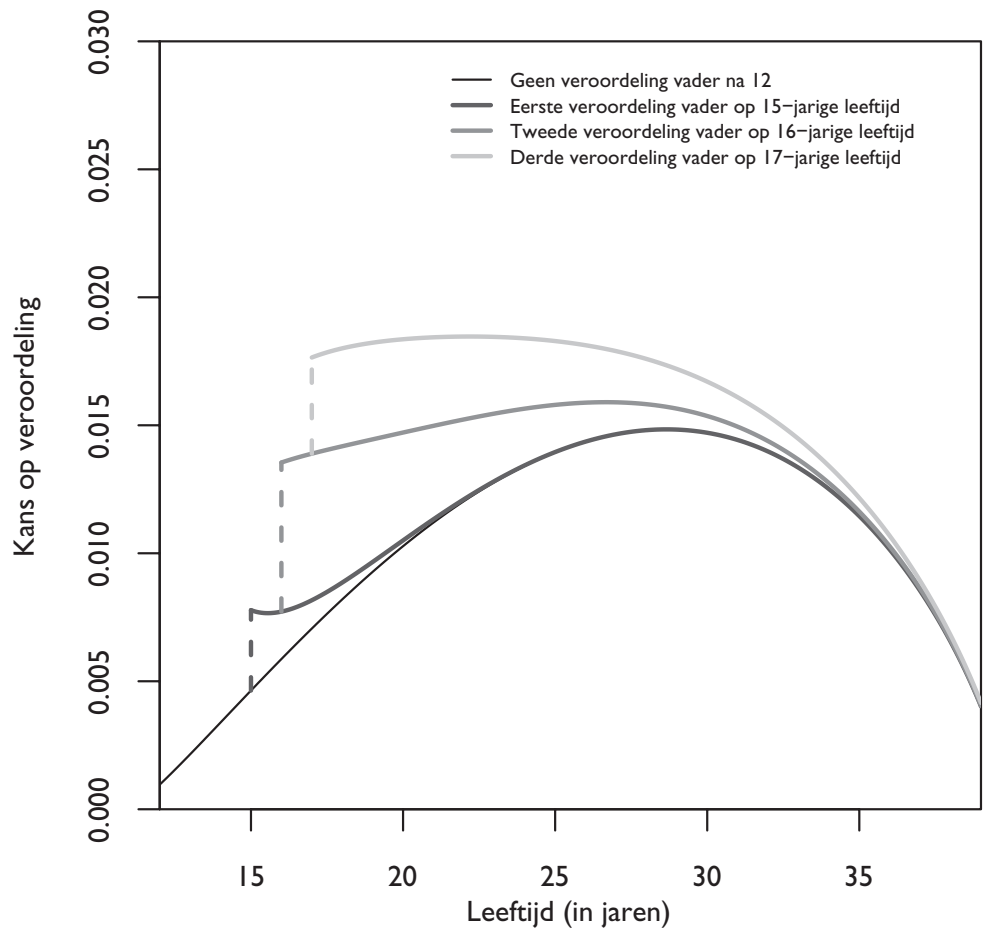

Figuur $1 b$ Vervaleffecten t.o.v. leeftijdscriminaliteitscurve

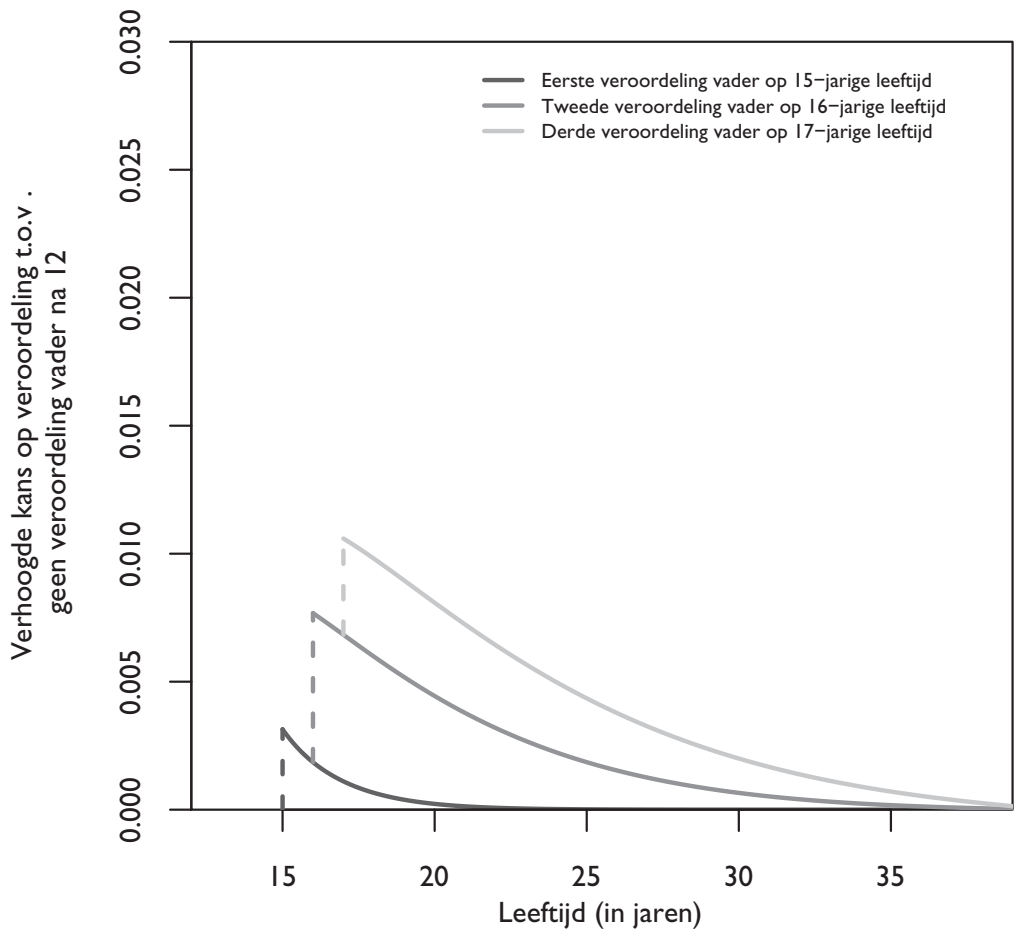


name optreedt bij meerdere delicten van de vader. De Statische hypothese wordt aldus verworpen.

In figuur 1 presenteren we de dynamische effecten berekend op basis van model 3, waarbij we alle controlevariabelen op hun gemiddelden hebben gesteld. In deze figuur is het verloop te zien van (1) de carrière van een kind (zoon) wiens vader geen delicten pleegde na het 12e levensjaar van een kind, (2) de carrière van een kind wiens vader het eerste delict pleegde toen hij 15 jaar oud was, (3) de carrière van een kind wiens vader het tweede delict (na het 12e levensjaar van het kind) pleegde toen hij 16 jaar oud was en (4) de carrière van een kind wiens vader het derde delict pleegde toen hij 17 jaar oud was. We presenteren de volledige levenslopen (1a) en de veranderingen ten opzichte van de oorspronkelijke leeftijd-criminaliteitscurve (1b). We zien dat de kans op een veroordeling stijgt in de jaren dat een vader een delict pleegt. Vervolgens neemt de kans langzaam weer af tot het oude niveau. We zien dat de afname bij het eerste delict (als het kind 15 jaar oud is) veel sneller verloopt dan bij het tweede en het derde delict (het bestendigingseffect). Bij het eerste delict is de halveringstijd slechts $1,58{ }^{*} \ln (2)=1,09$. De totale vervalparameter bij 3 delicten bedraagt $1,58+\left(\ln (3)^{*} 4,57\right)=6,06$ en de bijhorende halveringstijd is in dat geval $6,06^{*} \ln (2)=4,20$. Het verval verloopt aldus steeds langzamer.

De toetsing van onze aanvullende voorspellingen volgt in model 4 van tabel 2. In dit model zijn de parameters van de aanvullende effecten van echtscheiding en adolescentie op het vervaleffect en op het constante leereffect geschat. Onze verwachting was dat de leereffecten groter zouden zijn in de adolescentie en als ouders bij elkaar zijn, terwijl de vervaleffecten dan kleiner zouden zijn.

In model 3 zijn zowel de vervalparameter $\left(\beta_{2}\right)$ en de bestendigingparameter $\left(\beta_{4}\right)$ significant positief. Bij een nog nadere specificatie van het model (model 4) waarin ook de adolescentie en het wel of niet gescheiden zijn is meegenomen blijken beide parameters significant te zijn. We zien dat het leereffect na een scheiding $\left(\beta_{5}\right)$ significant negatief is. Wanneer ouders gescheiden zijn, dan gaat de kans voor een kind om een delict te plegen minder hard omhoog als een vader een delict pleegt, dan wanneer de ouders bij elkaar zijn. Hoewel scheiden zelf de kans op het plegen van een delict vergroot, blijkt de scheiding wel beschermend te werken tegen de negatieve invloed van een criminele vader. In sommige gevallen lijkt het erop dat echtscheiding ervoor zorgt dat kinderen niet langer onder invloed blijven staan van een criminele vader, waardoor de kans op delicten door die kinderen afneemt. Het leereffect in de adolescentie $\left(\beta_{6}\right)$ is significant positief, wederom conform onze verwachtingen. In de adolescentie (als de banden met ouders nog sterk zijn) gaat er een 
groter leereffect uit van de delicten die een vader pleegt dan in de perioden na de adolescentie. De parameters voor het vervaleffect bij scheiding $\left(\beta_{7}\right)$ blijkt niet significant. Bij adolescentie $\left(\beta_{8}\right)$ blijkt de parameter significant negatief. Dat betekent dat wanneer vaders delicten plegen tijdens de adolescentie het verval dan juist (relatief) groter is. Dit is tegengesteld aan onze verwachtingen. We dienen onze echtscheidingshypothese en de adolescentiehypothese daarom deels te verwerpen. Er blijken wel aanvullende effecten te zijn van echtscheiding en adolescentie op het leereffect, maar niet (in de verwachtte richting) op de mate van verval.

\section{Conclusie}

In deze bijdrage geven wij een antwoord op de vraag in hoeverre statische en dynamische theorieën de samenhang van criminele carrières van vaders met die van hun kinderen kunnen verklaren. Dit onderzoek draagt op verschillende manieren bij aan het vergroten van kennis over de intergenerationele overdracht van veroordelingen. Voor het eerst is expliciet gekeken naar de invloed van het tijdstip van delicten van de vader op het verloop van een criminele carrière van een kind. Daarbij is dit de eerste longitudinale studie waarin rivaliserende verklaringen betreffende de intergenerationele overdracht worden getoetst. De complete levenslopen van vaders en kinderen zijn daartoe naast elkaar gelegd. Ten slotte is deze studie met data van de Criminele Carrière en Levensloop Studie (CCLS) over complete levenslopen van 7987 kinderen en 4961 vaders (ook internationaal) de meest grootschalige studie naar de intergenerationele overdracht van veroordelingen.

In deze bijdrage toetsen we hypothesen vanuit twee theoretische stromingen. We toetsen allereerst voorspellingen uit de statische theorieën, die veronderstellen dat alleen omstandigheden in de zeer vroege kindertijd het criminele gedrag kunnen beïnvloeden. Volgens deze statische theorieën bestaat er wel een verband tussen het aantal veroordelingen van vaders en kinderen, maar berust dit verband op schijn. Vaders die veel delicten plegen hebben weinig zelfcontrole, kunnen geen kinderen opvoeden, waardoor hun kinderen ook weinig zelfcontrole verkrijgen. Als een gevolg daarvan plegen de kinderen ook delicten. Het precieze tijdstip van de veroordelingen van vaders doet er volgens de statische theorieën in zijn geheel niet toe. Vervolgens introduceren we voorspellingen vanuit dynamische theorieën die stellen dat er ook na de vroege kindertijd allerlei factoren kunnen zijn die de criminele levensloop beïnvloeden. Deze theorieën stellen dat er wel degelijk een invloed uit zal gaan van het precieze tijdstip van de delicten van vaders.

Uit de resultaten van het onderzoek blijkt dat er inderdaad een grote invloed uitgaat van de totale aantallen delicten die een vader pleegt. 
Daarnaast blijken er ook duidelijke effecten te zijn van het precieze tijdstip van delicten van de vaders. Deze effecten geven dus ook ondersteuning voor de tweede stroming: de dynamische (leer)theorieën. Uit onze resultaten blijkt dat de kans op een veroordeling hoog is in de jaren nadat een vader een delict pleegde. Al met al wijzen de resultaten op een gemengd beeld. Zowel statische als dynamische factoren beïnvloeden de kansen op crimineel gedrag.

Hoewel de statische theorieën in dit onderzoek en in eerder onderzoek met gegevens van de CCLS (o.a. Van de Rakt et al., 2008) gedeeltelijk worden bevestigd, lijkt de claim dat levensloopomstandigheden geen invloed hebben op de ontwikkeling van crimineel gedrag steeds te worden weerlegd. Auteurs over eerder onderzoek wijzen er ook op dat het statische gezichtspunt op de ontwikkeling van crimineel gedrag op zijn minst gesimplificeerd is (o.a. Blokland, 2005; Tittle, Ward \& Grasmick, 2003). Hoewel het uitgangspunt van de theorie - een bepaalde stabiele neiging tot crimineel gedrag over de levensloop - waarschijnlijk is, lijken nuances van de zelfcontroletheorie dus op zijn plaats.

Biologische theorieën die veronderstellen dat crimineel gedrag enkel en alleen door genetische overdracht wordt verklaard, worden met onze resultaten verworpen. Er blijkt in ieder geval ook een invloed uit te gaan van het precieze tijdstip waarop een vader de delicten pleegt. Voorspellingen gebaseerd op alleen genetica zijn in eerder onderzoek reeds veelvuldig verworpen (zie o.a. Van den Oord \& Rowe, 1997; Blokland, Thienpont \& Donker, 2005). Hedendaagse biosociale theorieën veronderstellen dat er op zijn minst een interactie tussen genen en omgeving (nature and nurture) zal bestaan (Blokland, Thienpont \& Donker, 2005). De uitkomsten van onderhavig onderzoek duiden ook op een dergelijke interactie.

Aangezien we in dit onderzoek uitsluitend gebruikmaken van officiele gegevens, beschikken we maar over enkele controlevariabelen. Idealiter zouden we meer controlevariabelen willen meenemen. Het verschil in sociale status tussen veroordeelde en niet-veroordeelde vaders zou wellicht een deel van het gevonden verband weg kunnen verklaren. Uit ander onderzoek blijkt wel dat de verklaringskracht van sociale status slechts beperkt is (Besjes \& Van Gaalen, 2008). Daarnaast zullen andere - door ons niet gemeten - factoren zoals opvoedtechnieken, buurt en gezinsstatus van invloed kunnen zijn. Toekomstig onderzoek zal uitsluitsel moeten bieden over de relatieve verklaringskracht van al deze factoren.

Een ander nadeel van de gebruikte officiële gegevens is dat onze data hoogstwaarschijnlijk een onderschatting van het werkelijke aantal gepleegde delicten zal betreffen. Veel delicten komen immers niet bij de politie aan het licht. Wanneer deze onderschatting niet selectief is, zal 
dit weinig gevolgen hebben voor de door ons gevonden relaties. Waarschijnlijk zullen de pakkansen voor sommige criminele vaders en hun kinderen echter groter zijn omdat zij intensiever door de politie in de gaten gehouden worden. Een groot voordeel van de officiële data is dat we sociale wenselijkheidproblematiek en geheugenproblemen geheel omzeilen aangezien we niet hoeven te vertrouwen op zelfrapportage. Daarbij zijn we in staat om meer ernstige vormen van criminaliteit te onderzoeken, vormen die veelal niet aan de orde komen in zelfrapportageonderzoek. We zijn er dan ook van overtuigd dat de officiële data de intergenerationele overdracht en de criminele levenslopen zo precies mogelijk in kaart hebben gebracht.

Hoewel de inzichten verkregen met dit onderzoek naar onze mening zeer waardevol zijn, dient er meer onderzoek verricht te worden naar alternatieve verklaringen voor het verband tussen veroordelingen van ouders en kinderen. Vervolgonderzoek zou zich bijvoorbeeld kunnen richten op de invloed van gevangenisstraffen en de specifieke invloed van echtscheiding op de criminele levensloop van kinderen.

\section{Noten}

1. Marieke van de Rakt is junior onderzoeker bij de sectie sociologie aan de Radboud Universiteit Nijmegen (m.vanderakt@maw.ru.nl). Stijn Ruiter is universitair docent bij de sectie sociologie aan de Radboud Universiteit Nijmegen. Paul Nieuwbeerta is senior onderzoeker bij het Nederlands Studiecentrum Criminaliteit en Rechtshandhaving en hoogleraar bij de sectie sociologie aan de Universiteit van Utrecht. Nan Dirk de Graaf is official fellow aan Nuffield College, Oxford. Deze studie werd mogelijk gemaakt door subsidie van NWO (NWO, 400-05-052). We danken Jochem Tolsma en de leden van de vakgroep sociologie voor hun commentaar op eerdere versies van dit paper.

2. Voor een volledig overzicht van de literatuur verwijzen we naar Van de Rakt, Nieuwbeerta \& De Graaf (2008).

3. We kiezen voor een logistisch model en niet voor een poisson of een negatief binomiaal model, omdat het aantal jaren waarin individuen meer dan 1 veroordeling hebben gekregen, verwaarloosbaar klein is.

4. Model 1 (zonder niet-lineaire effecten) is gebruikmakend van de lme4 package in R geschat met zowel 2 levels als met 3 levels. De verschillen in de grootte van effecten zijn zeer klein en leiden niet tot andere conclusies.

5. We kiezen ervoor om het leereffect te laten beginnen in het jaar dat een vader een delict pleegt en niet bijvoorbeeld een jaar later. We meten met onze data veroordelingen, waardoor er reeds een flinke vertraging tussen het plegen van het delict en onze meting zit.

\section{Literatuur}

Akers, R. \& Jensen, G. (2003) Social Learning Theory and the Explanation of Crime. New Brunwick: Transaction Publishers. 
Besjes, G.\& Gaalen, R.van(2008).Jong geleerd, fout gedaan? Bevolkingstrends ( $2^{e}$ kwartaal), 23-31.

Blokland, A. (2005). Crime over the life span: Trajectories of Criminal Behavior in Dutch Offenders. Alblasserdam: Haveka.

Blokland, A., Thienpont, K. \& Donker, A. (2005). Biosociale perspectieven in de criminologie. Tijdschrift voor criminologie, 47, 103-116.

Blokland, A., Nagin, D. \& Nieuwbeerta, P. (2005). Life Span offending trajectories of a Dutch conviction cohort. Criminology, 43(4), 919-954.

Blossfeld, H-P. \& Huinink, J. (1991). Human Capital investments or norms of role transition? How women's schooling and career affect the process of family formation. American Journal of Sociology, 97, 143-169.

Bruinsma, G. (1985). Criminaliteit als Sociaal Leerproces: een toetsing van de differentiële-associatietheorie in de versie van K.D. Opp. Arnhem: Gouda Quint.

Ebbinghaus, H. (1913). Memory: a contribution to experimental psychology. New York: Columbia University.

Farrington, D., Joliffe, D., Loeber, R., Stouthamer-Loeber, M. \& Kalb, L.(2001). The concentration of offenders in families, and family criminality in the prediction of boy's delinquency. Journal of Adolescence, 24, 579-596.

Farrington, D., Lambert, S. \& West, D. (1998). Criminal Careers of Two Generations of family members in the Cambridge Study in Delinquent Development. Studies on Crime and Crime Prevention, 85-105.

Fischer, T. (2004). Parental Divorce, Conflict and Resources: the Effects on Children's Behavior Problems, Socioeconomic Attainment, and Transitions in the Demographic Career. Wageningen: Ponsen \& Looijen b.v.

Fischer, T., De Graaf, P. \& Kalmijn, M. (2005). Friendly and Antagonistic Contact Between Siblings: A theoretical and empirical analysis. Journal of Family Issues, 26, 1131-1163.

Gottfredson, M. \& Hirschi, T. (1990). A general theory of crime. Stanford, CA.: Stanford University Press.

Harper, C. \& McLanahan, S. (2004). Father absence and Youth incarceration. Journal of research on adolescence, 13, 369.

Jaffee, S., Moffitt, T., Caspi, A. \& Taylor, A. (2003). Live With (or Without) Father: The Benefits of Living With Two Biological Parents Depend on the Father's Antisocial Behaviour. Child Development, 74, 109-126.

Nagin, D. \& Paternoster, R. (200o). Population Heterogeneity and State Dependence: State of the Evidence and Directions for Future Research. Journal of Quantitative Criminology, 16, 117-144.

Nieuwbeerta, P. \& Blokland, A. (2003). Criminal Careers of Adult Dutch Offenders (Codebook and Documentation). Leiden: NSCR.

McLanahan, S. \& Sandefur, G. (1994). Growing up with a single parent: what hurts, helps. Harvard: University Press.

Moffit, T.E. (1993). Adolescence-Limited and Life-Course-Persistent Anti- 
social Behavior: A developmental Taxonomy. Psychological Review, 10o, 674-701.

Oord, E. van den \& Rowe, D. (1997). Continuity and Change in Children's Social Maladjustment: a Developmental Behavior Genetic Study. Developmental Psychology, 33, 319-332.

Rakt, M. van de \& Nieuwbeerta, P. (2005) Criminal Careers of Adult Dutch Offenders and their children (Codebook and Documentation). Leiden: NSCR.

Rakt, M. van de, Nieuwbeerta, P. \& Graaf, N.D. de (2006). Zo vader zo zoon? De intergenerationele overdracht van crimineel gedrag. Tijdschrift voor Criminologie, 48, 345-360

Rakt, M. van de, Nieuwbeerta, P. \& Graaf, N.D. de (2008). Like father, like son? The relationships between conviction trajectories of fathers and their sons and daughters. British Journal of Criminology, 48, 538-556.

Rakt, M. van de, Nieuwbeerta, P. \& Apel, R. (2009). The association of criminal convictions between family members: the effects of siblings, fathers and mothers. Criminal Behaviour and Mental Health, 19, 94-108.

Rodgers, J., Buster, M. \& Rowe, D. (2001). Genetic and Environmental Influences on Delinquency: DF Analysis of NLSY Kinship Data. Journal of Quantitative Criminology, 17, 145-168.

Rowe, D. \& Farrington, D. (1997). The Familial Transmission of Criminal Convictions. Criminology, 35, 177-201.

Sampson, R. \& Laub, J. (1990). Crime and Deviance over the life course: the salience of adult social bonds. American Sociological Review, 55, 609627.

Smith, C. \& Farrington, D. (2004). Continuities in antisocial behavior and parenting across three generations. Journal of Child Psychology and Psychiatry, 45, 230-247

Sutherland, E., Cressey, D. \& Luckenbill, D. (1992). Principles of Criminology. New York: General Hall.

Tittle, C., Ward, D. \& Grasmick, H. (2003). Self-Control and crime/deviance: cognitive versus behavioral measures. Criminology, 19, 333-365.

Vold, G., Bernard, T. \& Snipes, J. (1998) Theoretical Criminology. New York/ Oxford: Oxford University Press.

Wixted, J. \& Ebbesen, E. (1991). On the form of forgetting. Psychological Science, 6, 1-11. 